\title{
Overview of the accessibility of webpages, related research, advantages, guidelines and recommendation
}

\author{
Csilla Prantner Kvaszingerné
}

\begin{abstract}
The essay aims to provide a survey of web accessibility, introduce the relevant research results along with describing the advantages of obstacle free webpages. Furthermore, I will attempt to promote the awareness of the significance of accessibility and equal access to information in case of educational webpages especially in the higher education sphere. My primary audience are educational policy makers and leaders of higher education institutions along with in-service teachers who regularly use webpages during their daily work with students struggling with various impairments. The article's focus is expanded onto the relevant professional and legal background, the most important accessibility principles in addition to discussing the tools assuring accessibility and the presentation of best practices for web developers elaborating the electronic learning environments for higher education institutions.
\end{abstract}

Key words and phrases: web accessibility, education, disability, universal design, higher education, WCAG2.0.

ZDM Subject Classification: A80, B40, D30, P50, R70, U50.

\section{Introduction}

\section{Accessibility support options in info-communication}

Accessibility support in the area of the info-communication is essential to ensure that everyone has equal opportunity to obtain information. Such applications as voice control of mobile phones, reading the screen content for the blind, the visually impaired and for children unable to read are vital means of information 
acquisition for certain groups of people. At the same time, the voice recognition service and the contrast display on the mobile phones and the magnifying option integrated in the operating systems are also included in this category. Webpages are the most effective devices for disseminating information, facilitating the electronic fulfilment of administrative errands along with reaching out to persons with disabilities. Being free of temporal and spatial restrictions, the Internet and the respective websites can provide significant help for abled and disabled people alike in information acquisition and taking care of administrative tasks related to official business. Consequently, obstacle-free accessibility of webpages is a crucial aspect of info-communication. Great care has to be taken to ensure that information uploaded on to a given webpage is freely accessible, in other words adequately visible, noticeable, and comprehensible for everyone regardless of physical condition or disability including blindness, vision or hearing impairment, mobility and age-related restrictions.

The scope, aims and the audience of the article

My primary objective is to provide an overview of the web accessibility phenomenon along with introducing the related research results and the advantages of obstacle free webpages. The survey will cover the various groups struggling with impairments, the main aspects of the WCAG 2.0 ISO/TEC international standard and the most important principles and guidelines. This will also indicate the great need for the accessibility of educational webpages for the disabled. Educational webpages include those maintained by instructors sharing educational support materials with students, e-learning systems facilitating individual material processing, academic administration systems, and the official webpages of higher education institutions. I also present research-based arguments and the needs of the disabled for those in educational administration and institution management while providing professional assistance for web development experts creating electronic learning environments and informatics teachers attempting to create webpages. Furthermore, besides the theoretical aspects I wish to present examples of best practices in web accessibility along with the introduction of a testing system ascertaining the accessibility of an educational webpage. I believe that the overall topic can be of interest for in-service teachers regularly using educational support webpages and dealing with disadvantaged students on a daily basis. 
Ensuring webpage accessibility in higher education-an overview of professional research literature

\section{International research results}

Accessibility to educational webpages and equal access to information are crucial concerns as students of the higher education sphere obtain most learningrelated information, do their academic work, and fulfil administration-related tasks via the Internet on-line. However, the concept of webpage accessibility should deserve priority not only because of its ability to help the disabled, but several abled students who commute and learn can get access en route to educational materials or texts only via the Internet. Most part-time students have full-time jobs and a significant portion of adult learners can be considered atypical learners, as they participate in individual, company-arranged, or other webbased knowledge acquisition schemes. All of the abovementioned groups rely on webpages to obtain learning-related information, data bases and functions on demand at any time. Furthermore, most disabled students can only gain access to essential information and services via the Internet. Although the disabled do not constitute a large portion of society, or that of the student population of higher education, the lack of accessibility options fully excludes them from the possibility of learning. The importance of accessible or obstacle-free webpages is emphasized by several international studies and research results. [14, 15, 20, 21, 22, 23] The Web Content Accessibility Guidelines (WCAG 2.0) published in 2008 with the recommendation of the World Wide Web Consortium (W3C) contains exact specifications and numerous recommendations for achieving webpage accessibility. The observation of these guidelines makes the web-based content accessible for more of the disabled and promotes a general usability improvement for non-disabled users as well. The role of the W3C in putting forth the recommendation is to call attention to the specification and promote the widespread application of accessibility leading to increased web functionality and interoperability. [5] Numerous studies focus on the instruction of web accessibility. [21, 22] The authors conclude that any further development or improvement in the field of accessibility requires the inclusion of the respective principles and technologies into instruction programs. While the Anti-Discrimination against and Remedies for Persons with Disabilities Act in 2008 assigned a formal priority to web accessibility and its instruction, in reality the training programs were not established. [22] One of the issues of the proceedings of the 2016 Web for All conference contained a suggestion that the relevant pedagogical culture be explored 
and thoroughly examined [21] in order to promote the inclusion of accessibility into education. The authors of the article discuss the obstacles to learning and the learning process in general according to the theoretical and practical aspects of pedagogy. They are on the opinion that accessibility in computer science education is a unique and challenging issue and a solution requires an additional effort from those concerned. Consequently, significant efforts should be made for the inclusion of accessibility education in academic curricula and the pedagogical profession should place a higher priority on the respective question. Having surveyed the relevant professional research results and texts according to quality and thematic distribution, the authors also concluded that the given field lacks a required pedagogical culture providing broad support to educational accessibility. [21] While web-based and technological development overall enabled humanity to enjoy heretofore unprecedented conveniences, the disabled, the elderly, and the disadvantaged could not fully take advantage of the respective benefits. In order to remedy the situation several research programs focused on the issue of webpage accessibility in case of higher education institutions. [14, 20, 23] One study focusing on the opening pages and those one step below included a retrospective analysis on the utilization of technological developments during the design stage. The correlation between the extent of web inaccessibility and the complexity of the given website was expressed by a calculated indicator figure. The research concluded that higher education websites become progressively inaccessible as they become more complex. [20] Another study included a comparative analysis of the webpages of 100 education institutions concerning compliance with accessibility requirements. [23] Furthermore, as a result of another unique research effort based on voluntary participation the webmasters of the given higher education institutions were asked to evaluate the extent of free accessibility of the webpages of their institutions. While the inquiry concluded that most higher education webpages do not meet the WCAG 2.0 guideline, there was one institution fully satisfying the AAA level of the WCAG 2.0 standard. The respective webpage served as a model of accessibility for its counterparts. It is all the more remarkable as the fulfilment of the AAA level is rather rare in case of any webpage, let alone an institutional one. [14] Experts promoting the importance of web accessibility use unique methods to emphasize the need for screen reading options. Besides introducing short-term courses in the topic, in a related experiment abled students had to use the screen reader as if they were blind and it was shown that such an equipment helps better understanding of the given content even for abled people as well. [4] While most people in the higher education sphere are aware 
of the importance of the accessibility of e-learning surfaces for disabled students, the exact implementation guidelines have not been elaborated yet. An important scholarly text titled, E-learning and disability in higher education: research and practice revised and published in 2013 contains the evaluation of current practices, describes the best solutions and presents the respective dissemination and propagation options as well. The second renewed edition places special emphasis on "sound"-based assistance in order to enable disabled students to maintain direct connection with the given technology and the institution where they learn. $[15]$

\section{Accessibility-related developments in Hungary}

Research results achieved in Hungary include two publications focusing on info-communication accessibility, especially web accessibility. In addition to these scholarly works providing appropriate guidelines and directions related to obstacle free educational webpages $[3,18]$ other works can be mentioned. The doctoral thesis of Andor Abonyi-Tóth completed in 2014 [2] analyses the accessibility aspects of LMS systems used both internationally and in Hungary ${ }^{1}$. The author substantiating or reinforcing international research results concludes that none of the examined systems met even the A level qualification criteria of the WCAG 2.0 standard. Other studies focused on the accessibility of webpages performing public service $[24,25]$, and in a previous essay I emphasized the importance of instructor webpage accessibility as well. [16] Moreover, in my doctoral dissertation I introduced the design and implementation process of an instructor portal system soon to be available free of charge ${ }^{2}$. Consequently, instructors can maintain a webpage for the support of their own instruction process. Naturally, the design process placed a high emphasis on accessibility concerns. The description of the implementation effort utilizing primarily the two previously mentioned works at the beginning of the paragraph is found in the second chapter of my dissertation. However, my work begins with the introduction of the concept of info-communication accessibility and with an overview of the most important accessibility principles.

\footnotetext{
${ }^{1}$ Blackboard, ILIAS, Desire2Learn, Moodle, Sakai.

${ }^{2}$ The realization of this goal requires the purchasing of servers financed by educational support grants
} 
The concept of info-communication accessibility, legal regulations and groups targeted for obstacle free access

The concept of info-communication accessibility and the provision of obstacle free access to webpages

The obstacle free accessibility of webpages mostly implies equal opportunity in accessing the given content. Accessibility support or obstacle free access in informatics is similar to the established practice in architecture. Consequently, an obstacle free building can be accessed by a person in a wheelchair and the respective notices and announcements are available in Braille, while even a person with a short stature can reach the elevator button as well. An obstacle free webpage allows everyone to use it regardless of potential disability, illness, availability of browsing device, or the level of familiarity with informatics.

Provision of obstacle free accessibility to webpages performing public service

For websites maintained by governmental organizations or service providers easy use and obstacle free access are essential. This is not only reasonable, but warranted by several pieces of legislation. (Legislation assembled [3]).

a. Equal opportunity law: Act XXVI/1998 on the rights and equal opportunity of disabled persons calls attention to the free accessibility of the built-in environment and the significance of accessibility to information deemed to be of public interest. [12]

b. Riga declaration (2006): The Riga Declaration calls for full accessibility to governmental webpages according to W3C standards.

c. European Parliament Resolution (2002): Accordingly webpages fulfilling public service functions must be made obstacle free and accessible while meeting the WCAG 2.0, WAI, and ATAG web standards.

d. Agreement on the rights of persons living with disability and the related Optional Protocol (2006): It stipulates that for organisations performing governmental and public service tasks provision of obstacle free access is mandatory.

e. European Commission: The Commission is implementing a decision on establishing a model accessibility statement in accordance with Directive (EU) 2016/2102 of the European Parliament and of the Council on the accessibility of the websites and mobile applications of public sector bodies. [11] 
Groups targeted for obstacle free access

Next I will point out disadvantaged groups most frequently encountering difficulties during computer use (Table 1.). [18]

\begin{tabular}{|l|l|l|}
\hline Persons living with disability & \multicolumn{1}{|c|}{ Technologically disadvantaged } & \multicolumn{1}{c|}{ Special target groups } \\
\hline $\begin{array}{l}\text { 1. blind users } \\
\text { 2. vision impaired }\end{array}$ & $\begin{array}{l}\text { 1. unusual screen size } \\
\text { 2. colour blind and colour } \\
\text { vision deficiency }\end{array}$ & $\begin{array}{l}\text { 1. children } \\
\text { 2. the elderly }\end{array}$ \\
$\begin{array}{l}\text { 4. hearnig impaired, physically } \\
\text { disabled }\end{array}$ & 3. people with low education levels \\
$\begin{array}{l}\text { 5. people with epilepsy } \\
\text { 6. people with intellectual } \\
\text { disability }\end{array}$ & 4. people speaking foreign languages \\
7. speech impaired & or representing different cultures \\
\end{tabular}

Table 1. Groups targeted for obstacle free access

Furthermore, any one, without the limitations listed above can find him or herself in a temporary "disability" situation. A person with a broken hand or someone with carpal tunnel inflammation has difficulty to move the mouse, if at all, similarly to a physically disabled individual. If someone is tired, or his or her vision is blocked, or is recuperating from an eye operation can be categorized as vision impaired, and people in a noisy place or where loud use of computers is not permitted and no earphones are at hand can be considered temporarily deaf or hearing impaired. Consequently, website accessibility support helps not only the disabled, but enables everyone to overcome temporary difficulties and setbacks as well. [18]

\section{Web Content Accessibility Guidelines-WCAG 2.0}

The Web Content Accessibility Guidelines 1.0 (WCAG 1.0) as the first recommendation of W3C accessibility work groups (WAI Working Groups) became a web standard in 1999 to be superseded by the Web Content Accessibility Guidelines 2.0 (WCAG 2.0) in 2008. The WCAG 2.0 document includes basic principles, directives and performance criteria that applications and webpages have to meet and observe in order to qualify as accessible. [2]

The document [5] distinguishes three levels of accessibility: including A, AA, and AAA, where A represents the lowest level, or the minimum requirements to 
qualify as an obstacle free webpage. The respective levels are interdependent, thus in order to advance between them all criteria of the previous level and the next as well have to be fulfilled. Consequently, in order to qualify on level AA all A and AA criteria have to be met, while advancement to the AAA level implies the fulfilment of all previous requirements. [2] The structure of the Web Content Accessibility Guidelines 2.0 is revealed on Figure 1.

\begin{tabular}{|c|c|}
\hline PRINCIPLES & GUIDELINES \\
\hline 1. Perceivable & $\begin{array}{l}\text { 1.1. Text alternatives. } \\
\text { 1.2. Alternatives for time-based media. } \\
\text { 1.3. Different ways of content. } \\
\text { 1.4. Foreign and background separate of sounds and visual elements. }\end{array}$ \\
\hline 2. Operable & $\begin{array}{l}\text { 2.1. Keyboard accessibility. } \\
\text { 2.2. Enough time to process content. } \\
\text { 2.3. Seizures protection. } \\
\text { 2.4. Navigable and searchable. }\end{array}$ \\
\hline 3. Understandable & $\begin{array}{l}\text { 3.1. Readable and understandable. } \\
\text { 3.2. Predictable operation. } \\
\text { 3.3. Assistance avoid and fix errors. }\end{array}$ \\
\hline 4. Robust & 4.1. Compatibility users and technologies. \\
\hline
\end{tabular}

Figure 1. The structure of the Web Content Accessibility Guidelines 2.0

The term "blind-friendly" is incorrect and an improper solution as well

Webpages prepared as a result of government or EU supported projects are required to be obstacle free, that is meeting at least the A level of the WCAG criteria system. Unfortunately, project monitoring, mainly due to a lack of appropriately trained experts, does not extend beyond ascertaining the availability of the accessibility symbol. Consequently, the yellow pictogram with black dots revealing the obstacle free version of the given webpage after clicking appears to satisfy accessibility requirements for the blind. Yet, this arrangement is improperly named "blind-friendly" in Hungary. The term itself along with the respective mode of implementation is incorrect for the following reasons:

1. The texts on these pages are displayed with large size yellow letters on a black or navy blue background, Consequently, while this arrangement cannot help blind people, it is perhaps useful for the vision impaired. 
2. Assistance provided for the blind in itself does not qualify a given webpage as accessible since besides the blind several groups need support, even those without any disability.

3. The visually impaired category includes several groups as for some large size black letters on a white background are more visible while others can read large yellow letters on a blue or black background better. Consequently, people with low vision turn off the web-developer-defined format in the browser and substitute it with the easier to read css style.

4. Since the respective contents are not regularly updated, these pages can include obsolete information uploaded several years ago.

\section{Examples of web accessibility}

Web accessibility in general is not visible, and the real difference is not in the display, but in the coding or the appropriate designation of the given content.

Due to temporal restrictions I would like to highlight only a few examples while explaining the website accessibility concept. In case of displaying any content the needs of the given group coping with disability have to be taken into consideration.

\section{"Principle 1: Perceivable"}

Guideline 1.1. Text Alternatives: For any non-textual content a textual alternative such as large print, Braille, speech, symbols or simpler language should be provided.

How do blind people surf on the Internet? One such method is the use of a relevant software, such as Jaws, that makes the content of the given screen audible. While texts printed on pictures cannot be read, all written material on a specific webpage should be available as text in the code of the given webpage.

Thus obstacle free presentation requires that non-textual content should have text-based alternatives.

1. In case of pictures the given image is described in a few words by a developercreated text while the respective picture can be found by the Google Search system.

2. In case of video the textual version of the given video should be provided in a separate text file to be uploaded on YouTube along with the respective video. What are the benefits of such approach? 
a. The errors in the subtitles can be corrected as the given lines are not printed on the video, but are contained by the attached text file.

b. The text can be translated into foreign languages and attached to the given video.

c. Due to the textual version the words heard in the video can be searched.

d. Hearing impaired users can read the text as well.

e. Non-disabled persons, sitting in a restaurant or on a public transport vehicle and unable to hear the given content properly can read the textual version.

f. Non-disabled people at a quiet location, such as a library can read the text of the video even without an earphone.

g. In case of foreign language texts the blind or visually impaired can access a voiced version of the Hungarian language equivalent.

h. In case of foreign language texts non-disabled persons can read the translation as well.

i. If the video and its subtitles are in a foreign language the given words can be translated after inserting the content of the text file in the Google Translator.

j. If the given sound is of low quality and not well understandable the texts can be made audible by the screen reader.

3. Structuring the given webpage: The beginning and end of the headlines, subtitles, and paragraphs in the given HTML documents should be exactly marked. Screen readers do not make the whole webpage audible, a click on a fast key reveals only the headlines, the titles, or the given links.

4. Composing the texts of the links. Special care should be taken when composing the given texts since those words are read for the blind user and this can have an impact on the search engine hit list as well. The text should provide an exact description of the information to be revealed after clicking along with enabling access to as large a surface as possible.

5. In case of electronic application forms care must be taken that not only the colour provides information as this can cause difficulty for persons with colour vision deficiency. Thus instead of colours the asterisk $\left(^{*}\right)$ should be used when marking mandatory areas.

Guideline 1.4. Distinguishable: "Make it easier for users to see and hear content including separating foreground from background" 3

${ }^{3}$ Quote from WCAG 2.0. 1.4. part [7]. 
Observing the distinguishability principle:

1. The background and the letters of the given text should be in adequate contrast.

2. The background and the main text should be separate in the audio file.

\section{"Principle 2: Operable"}

This segment focuses on several areas, including the given surfaces and the availability of each function via the keyboard, problem free navigation and the allocation of sufficient time for reading, viewing, and using the given contents. In the following section I provide a brief discussion of the respective keyboard specifications.

Guideline 2.1 Keyboard Accessible: Make all functionality available from a keyboard:

According to accessibility guidelines all keyboard indicated functions should be available by clicking on the TAB button or via moving the cursor arrows. The required elimination of keyboard traps is based on the movability of buttons and focal points referring to the entry fields via the keyboards. Adherence to this guideline provides help for various groups struggling with impairment. On the one hand for the vision impaired and the blind texts located on particular buttons are recited by screen reader software while describing the jlabelivalue of certain fields indicated by the cursor. On the other hand, since most physically disabled do not possess fine motor skills required for using the mouse, they access the functions of a given surface via the keyboard.

\section{What are the advantages?}

Website accessibility is simultaneous with several other objectives including mobile design, independent use regardless of device, multimodality, usability, and search optimalisation. Research results prove that accessible webpages can be searched easier, have lower maintenance costs, and can be read by more users.

\section{Universal Design}

Universal design implies a planning process of products accessible and usable by persons, in different age groups, with a broad scale of abilities, disabilities and characteristics. [9] The Universal Design process results in products, services, and 
an environment serving people with varying demands and abilities. Observation of the universal design principles can reduce the need for assistance technology to a minimum. [17]

The seven basic principles of Universal Design according to the abovementioned two sources [9]:

1. Equitable Use, 2. Flexibility in Use, 3. Simple and Intuitive Use, 4. Perceptible Information, 5. Tolerance for Error, 6. Low Physical Effort, 7. Size and Space for Approach and Use.

The comparison of website accessibility and Universal Design leads to the following conclusions. While both approaches emphasize equal opportunity access and use, the former implies equal opportunity access to the contents (in architecture equal opportunity access to objects and devices are emphasized), Universal Design promotes equal opportunities for use regardless of one"s abilities. Furthermore, whereas the term "obstacle free access" implies a posterior search for special solutions promoting equal chance accessibility especially for people coping with disadvantages, the Universal Design strategy as a more comprehensive approach takes into consideration the potential differences between users at the beginning of the design process. [8] Such approach observing ages, sex, or nationality is aimed at persons with disability and the non-disabled as well. Consequently, the respective buildings, objects, and devices are designed according to the varying abilities and competences of users while striving for universal and more uniform use of spaces, objects, and software instead of searching for situation-specific solutions.

\section{Universal Design for Learning (UDL)}

The principles of UDL were first established by Anne Meyer and David Rose at the beginning of the 1990s. The UDL reflecting the analogy of the Universal design process was adapted to the field of education. The model is based on the following three principles [6]:

I. Provide Multiple Means of Representation: learners can perceive and receive information in different ways. Since no single device is optimal for all learners, a variety of representational devices, that is, informational alternatives have to be provided for them.

II. Provide Multiple Means of Action and Expression: since there is no single device promoting action and expression, which is suitable for everyone, a wide variety of means should be provided.

III. Provide Multiple Means of Engagement: each learner can be motivated in a different way and everyone has their favourite modes of working or 
learning. There is no single solution applicable across the board thus several means of engagement should be available.

The current importance of this field is indicated by the organization of the Universal Design and Higher Education in Transformation Congress (UDHEIT2018) in Dublin at the end of October 2018.

Report on a survey on the accessibility of educational webpages and framework systems

In order to ascertain the levels of the accessibility of educational web pages via empirical tests I wish to introduce the results of three surveys. The three surveys focused on popular LMS systems, instructor portals, and the websites of highly ranked educational institutions respectively.

\section{Assessing the accessibility of Learning Management Systems (LMS)} (2014)

I would like to illustrate the accessibility levels of LMS framework systems via a quantified statistical analysis published by Andor Abonyi-Tóth in his doctoral thesis in 2014. His findings were introduced at the CSUN 2013 [1] conference in the presentation of DAN HAHN, HADI RANGIN, MARC THOMPSON titled "Comparison of LMS Accessibility Revisited". The research focused on the following systems: Blackboard 9.1, Desire2Learn 10, Moodle, Sakai 2.8. The LMS were evaluated according to 13 accessibility criteria. The four LMS were selected according to a popularity list prepared by the Capterra company considering the number and on-line presence of the users. Accordingly, the 4 LMS were ranked $3 \mathrm{~d}, 7 \mathrm{th}, 1 \mathrm{st}$, and 16 th respectively. The comparative analysis was performed with 13 factors and Table 2 below shows the minimum, maximum, and average results as well. The respective factors are included in the dissertation. [2]

While the quantified results appear to be attractive, the textual part of the evaluation reveals that the given systems were not accessible, and in some cases could not have met even the "A" level of the WCAG 2.0 guidelines. The respective details are found in the dissertation. [2]

It is worthwhile to compare the scores of the Moodle obtained via an earlier test performed by Viktor Fehér (2012) with test results indicating full compliance with WCAG 2.0 standards. [2] (Table 3.) 


\begin{tabular}{|c|c|c|c|c|}
\hline LMS name & Statement & Min. & Max. & Av. \\
\hline Blackboard 9.1 & $\begin{array}{l}\text { scored above } 90 \% \\
\text { in seven categories, } \\
\text { with an average } \\
\text { value of } 62,60 \% \text { and } \\
\text { a minimum value of } \\
27,78 \% \text {. }\end{array}$ & $27,78 \%$ & $52,54 \%(1)$ & $62,60 \%$ \\
\hline Desire2Learn 10 & $\begin{array}{l}\text { scored above } 90 \% \text { or } \\
\text { more in } 7 \text { categories }\end{array}$ & $52,54 \%$ & $100 \%(1)$ & $87,73 \%$ \\
\hline Moodle & $\begin{array}{l}\text { scored above } 90 \% \\
\text { in } 4 \text { categories, with } \\
\text { an average value } \\
\text { of } 75,39 \% \text { and a } \\
\text { minimum value of } \\
44,07 \%\end{array}$ & $44,07 \%$ & $100 \%(1)$ & $75,39 \%$ \\
\hline Sakai 2.8 & $\begin{array}{l}\text { scored at or above } \\
90 \% \text { in two cat- } \\
\text { egories, with an } \\
\text { average value of } \\
70,56 \% \text { and a min- } \\
\text { imum value of } \\
35,29 \% \text {. }\end{array}$ & $35,29 \%$ & $100 \%(2)$ & $70,56 \%$ \\
\hline
\end{tabular}

Table 2. The results of the LMS accessibility tests

\begin{tabular}{|c|c|c|c|c|c|c|c|c|c|}
\hline & \multicolumn{3}{|c|}{ "A" level } & \multicolumn{3}{|c|}{ "AA" level } & \multicolumn{3}{|c|}{ "AAA" level } \\
\hline Guidelines & 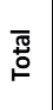 & 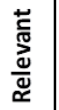 & $\frac{\text { d }}{\frac{\underline{\underline{\underline{4}}}}{3}}$ & 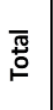 & 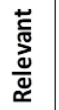 & 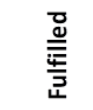 & 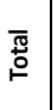 & 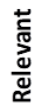 & 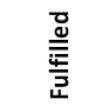 \\
\hline 1. Perceivable & 9 & 6 & $1(17 \%)$ & 5 & 3 & $2(67 \%)$ & 8 & 3 & $0(0 \%)$ \\
\hline 2. Operable & 9 & 9 & $5(56 \%)$ & 3 & 3 & $1(33 \%)$ & 8 & 8 & $5(63 \%)$ \\
\hline 3. Understandable & 5 & 5 & $4(80 \%)$ & 5 & 5 & $2(40 \%)$ & 7 & 7 & $3(43 \%)$ \\
\hline 4. Robust & 2 & 2 & $0(0 \%)$ & 0 & 0 & $0(0 \%)$ & 0 & 0 & $0(0 \%)$ \\
\hline Total & 25 & 22 & $10(45 \%)$ & 13 & 11 & $5(45 \%)$ & 23 & 18 & $8(44 \%)$ \\
\hline
\end{tabular}

Table 3. Results of testing the Moodle LMS by WCAG 2.0

Table 3 reveals to what extent the "A", "AA", and "AAA" level requirements of the WCAG 2. 0 criteria system were actually fulfilled. Since in its basic or 
beginning state the framework system does not contain time-regulated media, (sound or video) the respective guidelines are not relevant as it is indicated in the Table. The column titled "Fulfilled" displays the percentage values related to the number of relevant fulfilment requirements. The Table shows that the Moodle framework system meets $45 \%$ of the relevant "A" criteria, thus it cannot be considered accessible even at the lowest "A" level.

In this section I introduce the results of testing the accessibility of institutional webpages of three famous Hungarian universities with code validators and accessibility control devices (Table 4). The participating universities were selected according to the HVG magazine ranking in 2018. [10] Accordingly, ELTE University was ranked first, Szeged University placed second, and Pázmány Péter Catholic University was third. The institutional webpages were tested with the WAVE accessibility tester, and the W3C HTML and CSS validators.

Finally, I examined the most frequently used academic administration and arrangement system, the Neptun. While the accessibility level could not have been tested due to the inability of the WAVE to access its code, the HTML validator indicated 29 errors, and 1 warning, and the CSS validator detected 0 errors.

Examining the accessibility of instructor portals, (2014)

This survey performed in 2014 analysed the webpages of four Hungarian instructors employed by Hungarian higher education institutions and two American professors at Harvard University. The survey focused on accessibility and utilized the WAVE software [29]. The 6 webpages were chosen after a thorough selection process. Three websites were maintained by professors of Pedagogy and the other three were prepared Informatics experts. The webpages of foreign teachers were chosen after exploring the respective MOOC courses in Informatics and Pedagogy. The Hungarian webpages covering the field of Informatics were maintained by two professors at ELTE University and the Pedagogy related webpages were run by two acclaimed experts at Eszterházy Károly College. The respective article includes the addresses of the given webpages. [16]

The accessibility test in case of the website of the American informatics professor revealed 1 error and 4 alerts and the structural analysis showed that the editor of the webpage made a basic accessibility-related mistake since during the elaboration of the structural layout he used a table instead of CSS data. At the same time the webpage did not even meet the lowest "A" level 1.1 guideline as 
the picture on the opening page is not accompanied with an alternative description. The survey of the webpages of Hungarian Informatics experts proved that not counting one missing ih1 $i$ tag the webpage met the "A" level accessibility requirements of the WCAG 2.0. In case of the Pedagogy professors? webpages the WAVE [29] indicated a few errors, 4, 8, or 10 as these problems were caused by the deficiencies of the tags of the level 1 title lines and that of the alt attributes of the pictures. The least errors were found on the American webpage. The webpages, however, did not perform well in a code validator test, which is a criterion closely connected with accessibility. The HTML validator [28] of the W3C organization detected 2, 5, and 34 errors on the webpages of the Informatics experts respectively, while the webpages of Pedagogy professors revealed 5, 19, and 29 mistakes, In both cases the medium error level was detected in the American instructor's webpage. The number of HTML errors is largely determined by the codes of freely used templates. The Informatics experts' webpage revealed 4 and 11 errors on a given page, and there was a page on which no error was detected by the CSS validator [27]. At the same time the webpages of Pedagogy professors revealed 8 and 23 errors on a given page and the CSS3 code of one page was proved to be valid. In case of Informatics a valid CSS code was detected on the webpage of a Hungarian instructor and in case of Pedagogy on the webpage of an American instructor.

Evaluating the accessibility of the official webpages of higher education institutions (2018)

In this section I introduce the results of testing the accessibility of institutional webpages of three famous Hungarian universities with code validators and accessibility control devices (Table 4.). The participating universities were selected according to the HVG magazine ranking in 2018. [10] According to ranking the first universities are: 1. Eötvös Loránd Tudományegyetem, 2. Szegedi Tudományegyetm, 3. Pázmány Péter Katolikus Egyetem. I tested the homepages of the universities' webpages with WAVE accessibility tools, W3C HTML validator and CSS validator.

During the testing of the HTML, the CSS code it is not necessary to check each subpage with separate validators as the structure, or framework of the given pages is similar, and in case of template use they are identical. The segments which contain different information content show very low percentage difference. Consequently, no major discrepancies can be discerned regarding the HTML codes of the pages of the given site, thus the testing of the main page provides reliable 
information concerning the appropriateness of the rest of the pages. In case of analyzing the pages of the site we would receive similar results.

\begin{tabular}{|c|c|c|c|c|c|c|c|c|c|}
\hline & \multicolumn{6}{|c|}{ WAVE } & \multicolumn{2}{|c|}{$\begin{array}{l}\text { HTML } \\
\text { validator }\end{array}$} & \multirow{2}{*}{$\begin{array}{c}\begin{array}{c}\text { CSS } \\
\text { validator }\end{array} \\
\text {. } \\
\stackrel{n}{\frac{5}{4}}\end{array}$} \\
\hline Universities & 高 & $\frac{\stackrel{n}{\omega}}{\frac{\tilde{\omega}}{\alpha}}$ & 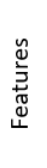 & 总 & 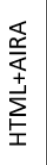 & 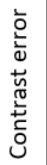 & $\begin{array}{l}\frac{n}{0} \\
\frac{5}{4}\end{array}$ & 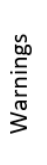 & \\
\hline https://www.elte.hu/ & 24 & 71 & 30 & 95 & 81 & 25 & 15 & 6 & 5 \\
\hline http://www.u-szeged.hu/ & 6 & 123 & 27 & 41 & 7 & 48 & 10 & 43 & 18 \\
\hline https://ppke.hu/ & 1 & 9 & 17 & 30 & 5 & 36 & 3 & 10 & 8 \\
\hline
\end{tabular}

Table 4. Test of webpages of three famous Hungarian universities

The Table 4 reveals that none of the three universities performed well on the automatic accessibility test administered by the WAVE software [29] as the HTML validator revealed several errors in case of all institutions of the sample. It can be concluded that if the institutional webpages are not fully accessible visitors will experience difficulty in obtaining information. I believe that for webpages supporting academic administration and those where instructors share educational support materials accessibility is an important requirement.

Tools for checking the compliance of webpages with standards

\section{The HTML validator}

In case of checking whether the given webpage meets specific standards the focus is on the appropriateness of the HTML and CSS codes. Thus the question emerges whether the HTML documents placed on the Tanitlap website meet the requirements of the HTML5 standard, or whether the given style files contain valid codes supported by the CSS3 standard as specified by the validators of the W3C Organization. The respective webpage codes can be easily checked by the W3C validators at no cost (Figure 2.). During checking the codes of the Tanitlap I relied on these validators. Accordingly, the URL of the given webpage can be inserted into the W3C Markup Validation Service website [28]. At the More Option section the HTML5 standard can be selected and the control process starts with a click on the Check button. 


\section{Markup Validation Service}

Validate by URI Validate by File Upload Validate by Direct Input

Validate by URI

Validate a document online

Address: httpi//tanitlap,uni-eger,hu/asilla

- More Options

Character Encoding (detect automatically)

Document Type

- List Messages Sequentially $O$ Group Error Messages by Type

$\square$ snow Source $\quad \square$ Clean up Markup with HTML-Tidy

$\square$ show Outline $\quad \square$ valicate error pages $\quad \square$ verbose Output

Check

Figure 2. The W3C HTML validator surface

If a webpage is constructed according to the HTML5 standard and includes a respectively valid code, it is ranked higher on the Google search list. Consequently, compliance with standards is a significant factor in optimizing the search options of a given website.

\section{The CSS validator}

The W3C CSS Validation Service (Figure 3.) provides a free validator for checking the appropriateness of the CSS code [27]. The given website offers several opportunities for checking the codes. If the URL of the page to be checked is provided the simultaneously downloaded codes can be examined, or a specific ccs file can be uploaded, along with copying a specified CSS code into the text field. During the examination of the Tanitlap code I provided the respective URL address to the validator. Thus all the CSS codes downloaded during the use of the webpage can be tested.

A website is considered valid if the codes of all of its pages are valid. However, there is no need for checking every subpage or subsection with the HTML and CSS validators since the structure or "frame" of each page is similar. They are identical in case of templates, and even segments with differing content show only a little difference. Consequently, there are no significant discrepancies regarding HTML codes between the pages. Thus the results of testing the main page imply the appropriateness of the codes at the other pages. Furthermore, pages with differing types (with different templates) and those allocated to the points of the 


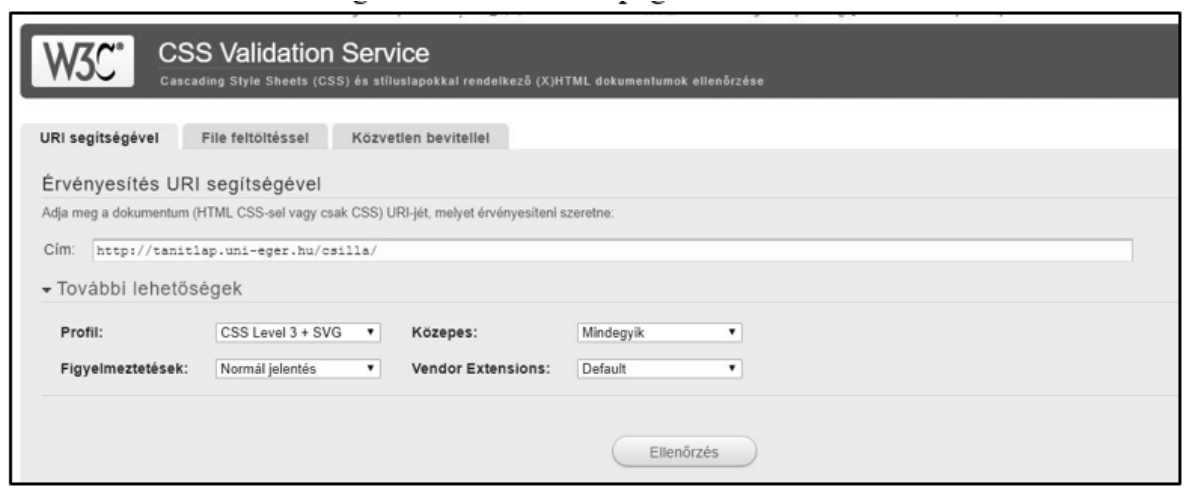

Figure 3. The surface of the W3C CSS validator

main menu should be checked separately. While in case of the CSS codes the same codes are downloaded, the pages connected with the given points of the main menu and those with differing templates should be checked separately.

Means for checking the accessibility of the websites

The Web accessibility Evaluation Tool (Wave) (Figure 4.) [29] provides adequate support for ascertaining the compliance of the given webpages with the WCAG 2.0 standard. This feature helps in identifying code level related accessibility deficiencies, includes a built-in colour contrast checker feature and is capable of monitoring the structure of the given webpages. Moreover, the system is familiar with WAI-ARIA [19] standard as well. Just like in case of the validators, the URL address of the given webpage has to be entered and a click on the ENTER button reveals the errors and warnings related to accessibility. The Wave option indicates the errors in context of the WCAG 2.0 standard with the icons located on the surface of the website. Accordingly, the icons appear at the location of the given errors and clicking on the icons provides further information on the respective error and the potential means of elimination.

The wave accessibility control feature provides a visual indication of structure related tags. It shows if the respective tags are recognized by the HTML5 and ARIA standards, and provides textual explanations with the pictures for checking the correctness of the alternative text. Such features help in ascertaining or surveying the accessibility compliance of the given website as well. 


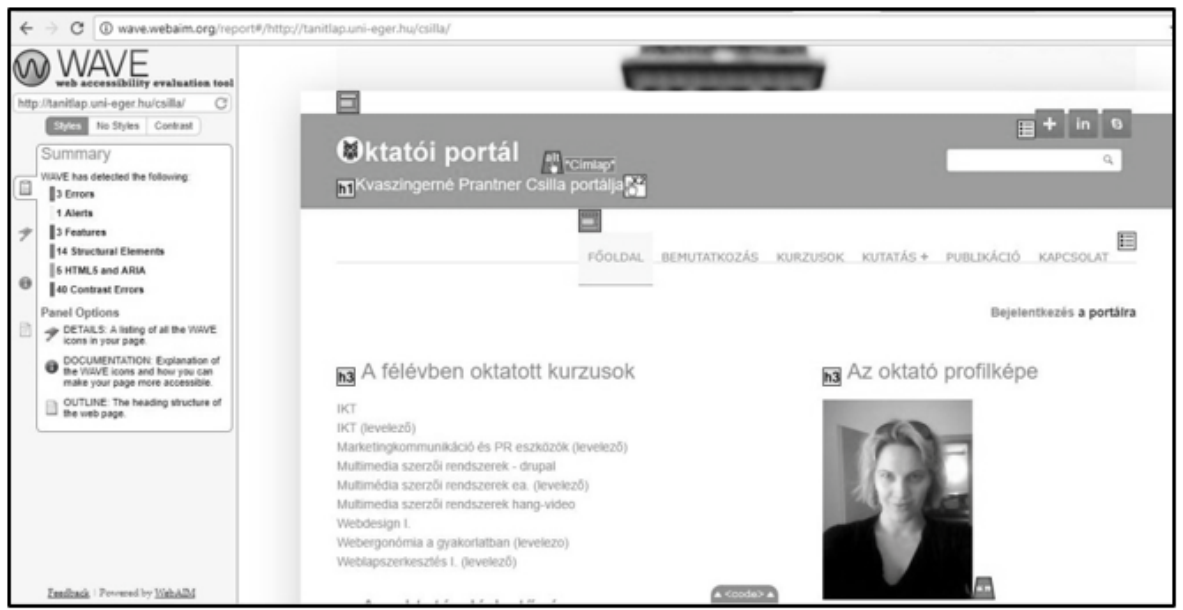

Figure 4. Checking the Tanítlap website with the Wave accessibility control feature

Both validation and the accessibility are considered recursive processes entailing (1) the identification of errors, (2) the respective corrections, followed by repeated error identification and correction. The successive repetitions take place until all the errors are corrected, especially until all the ERROR and WARNING messages are eliminated. A single repair step can solve 10-20 problems in case of global or comprehensive errors.

\section{Checking the colour contrast}

While the WAVE system indicates colour contrast-related errors, the colour contrast check feature [26] indicating whether the colour contrast on the given webpage meets the WCAG standard should be used as well. Furthermore, the contrast between the background and the character colour of the specific texts on the given webpage can be evaluated too (Figure 5.).

Checking the websites on various operating systems, browsers, and devices

The checking of the websites requires the viewing of the presentation, or display in a variety of devices, definitions and browsers. This condition is especially 


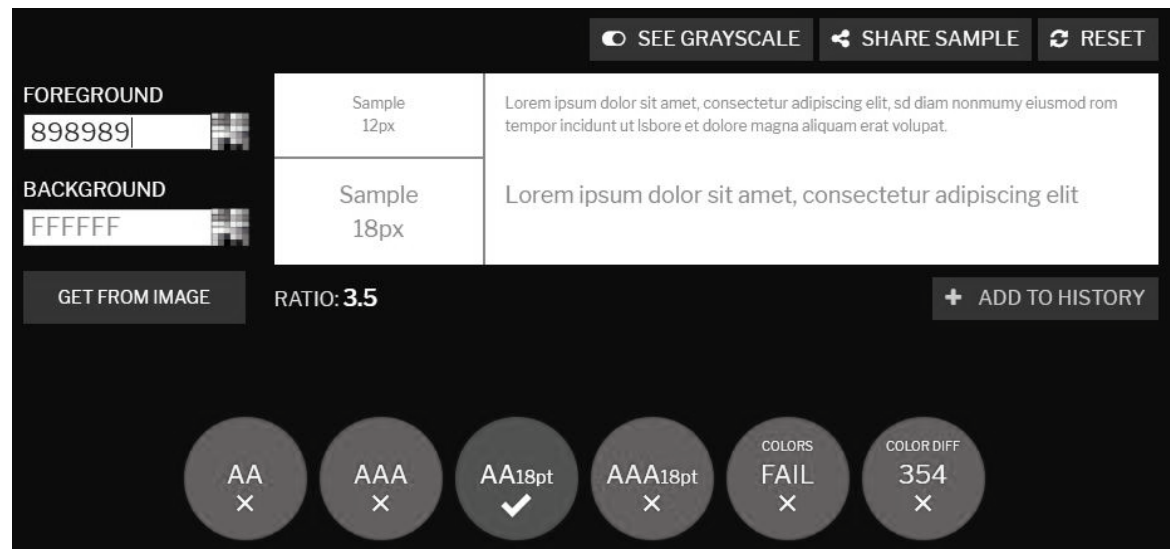

Figure 5. Checking the contrast between the background and the character colour of the Tanítlap webpage

important in case of websites supporting teaching and learning. Today's websites based upon the latest technology are constructed according to responsive web design adjusting the arrangement of content and the size of the pictures to the size of the screen in an optimal way. For the Tanitlap this is especially important as it is expected to be used mostly with PC work stations, laptops, tablets, or mobile phones. Since many students commute or learn while being employed tablets and mobile phones appear to be ideal for mobile-based learning. As a result of the responsive web design the contents are automatically arranged according to the size of the display screen of the given device. Consequently, it should be ascertained that the content is appropriately presented and the respective functions are operating properly in all types of devices regardless of search engines or operation systems.

Implementation of accessibility and standardization of the self-developed instructor portal framework system

Next I introduce the details, tools, and methods guaranteeing the accessibility of the instructor web-portal framework system developed as a result of my doctoral dissertation. The obstacle free instructor portal framework system was used and tested by 9 instructors of the Eszterházy Károly University via action 
research. The respective portal is expected to provide support for an increasing number of instructors and students.

\section{The Tanitlap portal framework and the thesis}

With the aim of providing assistance to fulfilling education and administration related tasks to instructors without a background in informatics and computer science in mind I designed and implemented a web-surface titled Tanitlap http://tanitlap.uni-eger.hu/csilla, last access: 18.04.2018.). Said instruction portal framework system will provide access to educational support materials and information for learners without spatial and temporal restrictions via a flexible, easy to use surface system. Supported by said web surface, instructors can share auxiliary or educational support materials with students in a pre-conceived and structured manner along with exchanging messages. During the design stage I surveyed a variety of design principles and models in the fields of Human Computer Interaction, web ergonomy, usability, user experience and obstacle free access. I placed special emphasis on meeting the latest web standards (HTML5 and CSS3), the inclusion of validator-reinforced codes, and the provision of obstacle free access ${ }^{4}$, while successfully performing on web ergonomic and usability tests.

\section{Thesis related to accessibility and standardization of the Tanitlap} portal framework system: It is possible to construct an instructor portal system based on Drupal with source codes HTML5 and CSS3 along with standards containing appropriate validated codes meeting the WCAG 2.0 A level criteria of the obstacle free accessibility.

While in case of the first theme version of the Tanitlap the sporadic errors identified by the validators were easily corrected [16], due to the increasing number of errors revealed by a web ergonomic test I changed the theme of the Tanitlap website into the one downloaded from Drupal.org. Since the portal framework system was prepared with Drupal the accessibility-related errors can be attributed to that system. Although the new framework had many advantages and corrected several deficiencies on the webpage, the validity of the code was significantly weakened. In the next two subchapters I discuss the theme of errors and warnings appearing after the style change along with the respective correction options.

\footnotetext{
${ }^{4}$ The system should meet the "A" level requirement of the WCAG 2.0 standard.
} 
Validation of the Tanitlap according to the HTML5 standard

Testing the main page of the textitTanítlap according to the HTML standard revealed 53 errors, It was beyond doubt that the given errors were caused by the two template files, (that is two php) namely, in the simplecorp theme folder and the page tpl.php or tanitlap sub theme folder determining the theme of the website. These generate the HTML of the website potentially causing errors in the code and to be examined by the validator.

\section{The types of the identified errors:}

(1) The first error type was related to incorrect type definition in the html, tpl. plp. It is considered an error if the code of the tested website does not reveal that the given document was prepared according to the HTML 5 standard and the browser does not realize that the given code has to be interpreted according to that standard. The error can be corrected by providing the type definition of the HTML5 documents, in the first line of the php code. Furthermore, the $<$ !DOCTYPE html $>$ term along with related unnecessary code segments should be deleted. This correction led to the elimination of 21 errors.

(2) The next major type of error is the uninterpretable value of the role attribute in the iheader role=" header" class=" container clearfix" $>$ component in the tpl.php. Since the validator cannot read or process the role="header" segment $^{5}$, the given code section can be deleted (Figure 6.). This step led to the elimination of one more error.

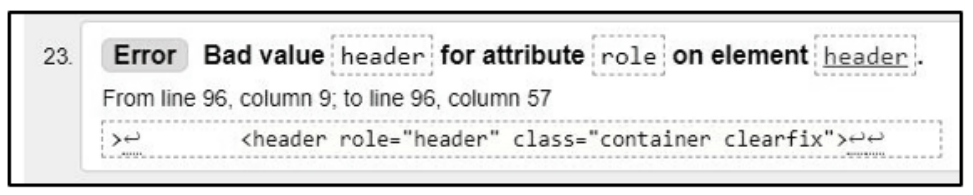

Figure 6. An error identified by the HTML validator

(3) According to validator in the code of the page.tpl.php file $<$ hgroup id="nameand-slogan" $>$ the $<$ hgroup $>$ tag can?'t substitute the $<\operatorname{div}>$ tag, because the $<$ hgroup $>$ tag is obsolete. The "hgroup?" is interchangeable for 2div". Two errors had been fixed.

${ }^{5}$ The role attribute is an attribute or component of the ARIA (Accessible Rich Internet Applications) system. The ARIA is a collection of a wealth of internet services and technologies detemining the quality of web-based content for the disabled. 
(4) The validátor said the role="navigation" assignment of $<$ nav $>$ tag is unnecessary. This is erasable from the page.tpl.php file code, because the browser can't interpret it. Another error had been eliminated.

(5) The validator doesn't mark all problems as error as in some less serious cases a warning is given. As a warning was indicated the a type="text/css" assignment of < style $>$ tag can be omitted, because this is not useful in HTML5. Probably this problem is related to the Drupal Core itself.

(6) The other group of WARNINGs is related to this type of attribute too. This the type $=$ "text/javasript" assignment of $<$ script $>$ tag is unnecessary. The Drupal Core put this unnecessary code into the HTML.

In case of the last two warnings neither the html.tpl.php nor the page.tpl.php included the respective terms. I solved the problem by searching for the abovementioned two expressions in the last saved full code by the GREP command in the Drupal Core folders. It was revealed that the common inc file located in the includes library contains such terms. After providing the textual explanations or comments only 19 errors were left. However, all errors were related to javascript. I commented on the 'type' $=>$ ' text/javascript' section and this eliminated all WARNING icons ${ }^{6}$.

Thus all the errors and warnings were corrected or eliminated on the given website and the code of the opening page of the Tanitlap website became valid according to the HTML5 standard.

Since the other pages of the portal are structured according to the same "framework", that is the same two php of the Core and the style generate the code, it can be deduced that the whole site is valid. In order to test this hypothesis I applied the validator according to the HTML5 standard to the following websites: Introduction: http://tanitlap.uni-eger.hu/csilla/bemutatkozas Courses: http://tanitlap.uni-eger.hu/csilla/kurzusok Research: http://tanitlap.uni-eger.hu/csilla/kutatas Research/Projects: http://tanitlap.uni-eger.hu/csilla/kutatasok_projektek A research case study: (ICAI szemmozgáskövetös vizsgálat): http://tanitlap.uni-eger.hu/csilla/node/82 Publications: http://tanitlap.uni-eger.hu/csilla/publikacio Connection: http://tanitlap.uni-eger.hu/csilla/kapcsolat

${ }^{6}$ It should be noted that in case of a repeated updating with Core such errors will re-occur in the system. If a continuously valid code is needed the incorrect ones should be eliminated manually and taken out by script after every updating. 
Course page (Webdesign I.): http://tanitlap.uni-eger.hu/csilla/node/68

In case of all tested pages the HTML code met the validity requirements of the HTML5 standard.

Validating the style sheets of the Tanitlap website according to the CSS3 standard

The CSS code of the Tanitlap website became invalid after its deficiencies were revealed by a usability test and a new style framework downloadable from the drupal.org was deployed. While the new theme the Simple Corp was presented on the drupal. org as its code meets the HTML5 and the CSS3 standard, contrary to its appearance, the codes were not valid. As a result of testing the Tanitlap website with the CSS3 validators 22 errors were identified.

\section{Type errors revealed in the CSS code:}

(1) The first error was related to the gradient of the backgrounds, as according to the error message the browser could not make sense of the term "linear-gradient" as it was presented by the code. The word "to" was missing from the maincss.css.simplecorp folder and this preposition had to be replaced in front of the first parameter of all the linear gradient terms. As a result of this maneuvre 12 errors were eliminated on the page.

(2) The term "webkit-border-radius" was not comprehensible in the main-css.css file. I replaced the hyphen in front of the term, thus 9 errors were left in the CSS code.

(3) The "inset 0 is not a color value" says the validator. The correct indication of 0 as a value of "inset", is not part of the "inset" word.

(4) The "opacity:0" code is incorrect in the "filter: alpha(opacity:0)" expression. The solution is using the opacity parameter equation sign ("="). This is the true syntax: "opacity=0".

(5) In the "display: the term "list" is a problem, the display hadn't a possible "list" value. If the validator and the w3school.com webpage do not recognize this expression and the browsers can't interpret it, this expression is erasable from the code.

(6) The validator analysis had detected an error according to the expression: "@pagemargin: 0.5cm;". The problem was the @media $\{. .$.$\} item included the$ @ page $\{\ldots\}$ item. The browsers couldn't interpret this complex expression. The solution is removing the @ page $\{. .$.$\} details from the @media \{. .$.$\} item and placing$ it before that. 
(7) The last two problems were related to the term "!important". In the 320.css and 480.css errors were detected: the expression "!important" was missing before the 0 value.

The CSS codes of the Tanitlap became valid according to the CSS3 standard. (Figure 7.)

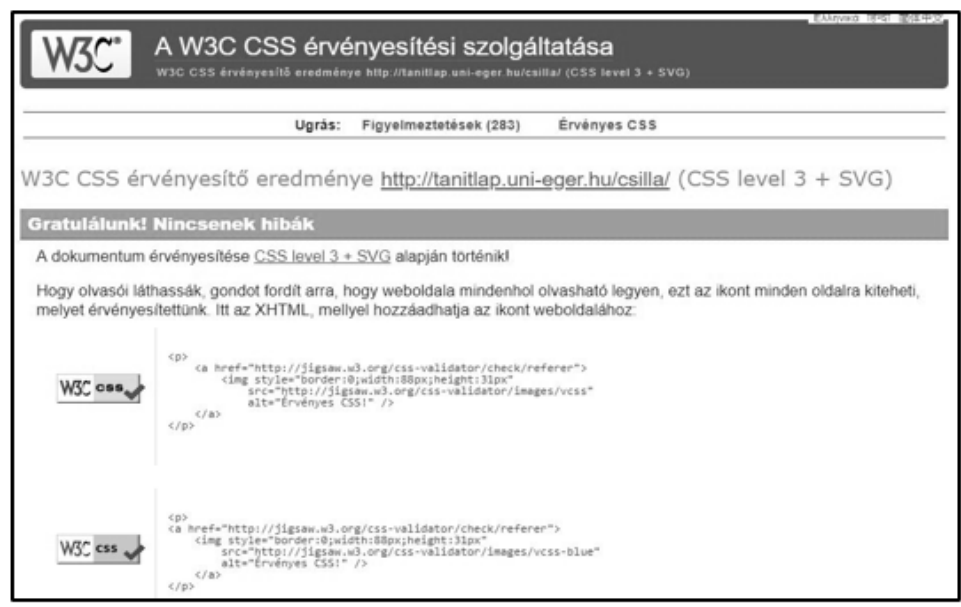

Figure 7. The website http://tanitlap.uni-eger.hu/csilla includes a valid CSS3 code

Testing the accessibility of the Tanitlap by the Wave option

I also examined whether the pages of the Tanítlap meet the guidelines of the A level of the WCAG 2.0 standard.

\section{The respective error types and their correction:}

(1) According to the first error three empty buttons were found without any content. The respective error was caused by the code-based deficiency of the minifile in the Colorbox module, the jquery.colorbox-min. In the file no value was allocated to the buttons marked Previous, Next, and Close and only the term: <button type="button" / > was indicated. It had to be complemented with an appropriate attribute.

(2) The second error meant that the same link was found in two components located close to each other: the logo and the name of the website beneath it. In order to correct the error I removed the link from the name of the website in the page.tpl.php. 
(3) The missing alternative text under the picture was the third error. It is up to the user, that is the instructor in this case, whether he or she provides alternative text to the uploaded picture. The Tanitlap provides such an option during uploading. Naturally, I corrected the error and uploaded an alternative text at my own portal.

(4) The fourth error appeared with the display of the headlines as the $<\mathrm{h} 1>$ type was followed by $<\mathrm{h} 3>$ instead of $<\mathrm{h} 2>$ type headlines in all the pages. While such errors did not occur in the framework downloaded from my own theme, in the new one downloaded from Drupal.org this error had to be corrected.

(5) The fifth error included 44 colour contrast related discrepancies identified by the Wave. The light grey (\#898989) colour was not in full contrast with the white (\#FFFFFF) background. Consequently, I replaced the \#898989 colour code with a darker one (\#595959) in the main css in 14 places. The hover status of the menu points had to be changed to a darker green (\#038358) in the styles.css in 2 places. Moreover, since the Wave indicated that the respective white textual parts in the heading bar do not show an appropriate contrast with that of the heading bar I made the colour of the latter darker green in the styles.css. The new colours were selected by the help of the contrastchecker website.

\section{Evaluation of the thesis}

The hypothesis established regarding the Tanitlap portal framework system was substantiated. I could construct a system whose codes meet the HTML5 and CSS3 standards according to the W3C validators along with meeting the "A" level accessibility guidelines of the WCAG 2.0 criteria. Although correcting the codes of the educational websites is a timeconsuming and difficult task, it is a mandatory component of the respective development process.

\section{Summary}

Research each into the theoretical, the legal background and the three survey justifies a great need for educational web page accessibility. In the view of some experts the realization of the goals of the accessible web requires the accreditation of accessibility-related courses offered by higher education institutions. Such 
developments are essential for the improvement of the situation and accessibility becoming a society-wide concern.

While several experts focus on this issue and a wide variety of professional results were published either in scholarly essay or blog forms $[2,3,16,18,24$, 25], webpage accessibility, its importance and implementation have not become a principal priority of web-page designers. These findings are substantiated by the three surveys as well.

However, the National Digital Education Strategy released recently in 2016 by the Hungarian government [13] emphasizes the importance of accessibility in digital instruction and learning and is expected to lead to the required changes, especially in the field of webpage accessibility.

My research effort resulting in the compilation of the most important guiding principles and methods in the field of accessibility bears relevance to the accessibility of teaching and learning websites. I developed a tested and barrier-free instructor portal framework system that can be used free of charge and I presented the validation and accessibility methods and their practical accessibility potentially helping educators, informatics professionals and all experts involved in the field of higher education. I hope this article and my personal commitment will underline the need for and reiterate the importance of obstacle free accessibility in case of web surfaces supporting the teaching and learning process. It is hoped that the present study will facilitate the realization of the need for accessible and obstacle free webpage design along with providing practical suggestions and advice for achieving webpage accessibility.

\section{References}

[1] 28th Annual International Technology and Persons with Disabilities Conference (California State University, Northridge), https://bit.1y/2FQFpwq, last access: 30.03.2018.

[2] Abonyi-Tóth Andor, Kollaboratív, internet alapú tanulási felületek tervezése és a tanulásban betöltött szerepének értékelése. Phd értekezés. ELTE PPK Neveléstudományi Doktori Iskola, Budapest, Témavezető: Dr. Turcsányi-Szabó Márta, 2014.

[3] Abonyi-Tóth Andor and Pataki Máté and Mátételki Péter, Bevezetés az infokommunikációs akadálymentesítés világába I. Fogyatékos Személyek Esélyegyenlőségéért Közalapítvány, Bp., 2011. 
[4] AP Freire, RP de Mattos Fortes, DM Barroso Paiva, Using screen readers to reinforce web accessibility education, Proceedings of the 12th annual SIGCSE conference on Innovation and technology in computer science education (2007), 82-86.

[5] B. Caldwell, and M. Cooper and R. L. Guarino and G. Vanderheiden, Web Content Accessibility Guidelines (WCAG) 2.0., 2008 https : //www . w3.org/TR/WCAG20/, last access: 30.01.2018.

[6] CAST [website], The UDL Guidelines, 2018, https://bit.1y/2IaxAP6, last access: 30.03.2018.

[7] Dan Hahn, Hadi Rangin, Marc Thompson, Comparison of LMS Accessibility Revisited, http://bit.1y/1bMetSo, last access: 30.03.2018.

[8] Disabilities, Opportunities, Internetworking, and Technology [website], What is the difference between accessible, usable, and universal design? 2017, http://bit.1y/1EFMGbB, last access: 30.03.2018.

[9] Disabilities, Opportunities, Internetworking, and Technology [website], What is universal design? 2017, http://bit.1y/2HIb92B, last access: 30.03.2018.

[10] Educatio website: Itt a HVG 2018-as felsőoktatási rangsora: ezek a legjobb egyetemek és föiskolák. 2018. https://bit.ly/2AAeTkX, last access: 30.03.2018.

[11] European Commission: Commission implementing decision on establishing a model accessibility statement in accordance with Directive (EU) 2016/2102 of the European Parliament and of the Council on the accessibility of the websites and mobile applications of public sector bodies, https://bit.1y/2Lio2Cf, last access: 18.04.2018.

[12] Government of Hungary, 1998. évi XXVI. törvény a fogyatékos személyek jogairól és esélyegyenlőségük biztosításáról, 1998, https://bit.1y/2s2zESc, last access: 30.03.2018.

[13] Government of Hungary, Magyarország Digitális Oktatási Stratégiája, 2016, https://bit.1y/2p7iumv, last access: 30.03.2018.

[14] Harper, Kelly A. and DeWaters, Jamie, A quest for website accessibility in Higher Education Institutions, Internet and Higher Education 11, no. 3-4 (2008), 160-164.

[15] JK Seale, E-learning and disability in higher education: accessibility research and practice, 2013.

[16] Kvaszingerné Prantner Csilla, Az oktatói portálok helye és szerepe a felsőoktatás hazai és nemzetközi gyakorlatában, in: INFODIDACT 2014: Informatika Szakmódszertani. Konferencia, (Szlávi Péter and Zsakó László, eds.), Budapest: Webdidaktika Alapítvány, 2014, 1-20, http://bit.ly/2xoosUI, last access: 21.05.2017.

[17] National Disability Authority. Centre for Excellence in Universal Design [website], What is universal design? without year, https://bit.1y/1oja8oe, last access: 30.03.2018.

[18] Pataki Máté and Abonyi-Tóth Andor, Bevezetés az info-kommunikációs akadálymentesítés világába II. Fogyatékos Személyek Esélyegyenlőségéért Közalapítvány, Budapest, 2011. 
[19] Rich Internet Applications, http://w3c.hu/forditasok/WAI-ARIA/, last access: 30.03.2018.

[20] S Hackett and B Parmanto, A longitudinal evaluation of accessibility: higher education web sites, Internet Research 15, no. 3 (2005), 281-294.

[21] S Lewthwaite, D Sloan, Exploring pedagogical culture for accessibility education in Computing Science, Proceedings of the 13th Web for All Conference 3 (2016).

[22] SG Hong, YM Kang and HM Lee, Web Accessibility. Education trends and discussion to vitalize web accessibility education, Journal of the Korea Industrial Information Systems Research 16 (2011), 73-87.

[23] SK Kane and JA Shulman and TJ Shockley, A web accessibility report card for top international university web sites, Proceedings of the 2007 international cross-disciplinary conference on Web accessibility (2007), 148-156.

[24] Szántai Károly, Akadálymentesweb.hu, szakmai blog az akadálymentességgel kapcsolatosan https://bit.1y/2GbAr8r, last access: 2018.01.30.

[25] Szántai Károly, Szántai Károly az m1 Esély müsorában a web akadálymentességi képzésekről YouTube-os videója, in: Akadálymentesweb.hu, 2014, https://bit.1y/2rIkpgK, last access: 30.03.2018.

[26] The Color Contrast Check Feature: https://contrastchecker.com/, last access: 18.04.2018.

[27] The CSS validator of the W3C organization: http://jigsaw.w3.org/css-validator/, last access: 30.03.2018.

[28] The HTML validator of the W3C Organization: http://validator.w3.org/, last access: 30.03.2018.

[29] The Web accessibility Evaluation Tool: http://wave.webaim.org/, last access: 30.03.2018.

CSILLA PRANTNER KVASZINGERNÉ

ESZTERHÁZY KÁROLY UNIVERSITY

3300, EGER, ESZTERHÁZY KÁROLY SQUARE 1.

HUNGARY

E-mail: kvaszingerne.prantner.csilla@uni-eszterhazy.hu

(Received June, 2018) 